\title{
Fenoliset terveyskomponentit marjantuotannossa
}

\author{
Reijo Karjalainen, Anne Hukkanen, Mikko Anttonen ja Kari Tiilikkala \\ Maa- ja elintarviketalouden tutkimuskeskus, 31600 Jokioinen, ja Kuopion yliopisto \\ PL 1627, 70211 Kuopio
}

\begin{abstract}
Tiivistelmä
Marjat ovat tunnetusti erinomaisia C -vitamiinin lähteitä, mutta vitamiinien ja kivennäisaineiden sekä kuitujen lisäksi marjoissa on runsaasti fenolisia fytokemikaaleja, joilla tiedetään olevan ihmisen terveyttä edistäviä ominaisuuksia. Nämä fytokemikaalit ovat kehittyneet kasveihin vuosimiljoonien aikana suojaamaan kasveja tauteja ja tuholaisia sekä muita stressejä vastaan. On biologisesti vain sattumaa, että nämä samat kasvin suoja-aineet on myöhemmin havaittu myös hyväksi ihmisen terveydelle. Marjojen tärkeimpiä fenolisia terveyskomponentteja ovat flavonoidit, joita kasveissa esiintyy yli 4000 erilaista yhdistettä. Viljellyistä marjoista mustaherukassa on eniten flavonoideja. Mansikassa ja vadelmassa on runsaasti fenolihappoihin kuuluvaa ellagihappoa, jolla tiedetään olevan antimutageenisia ja antikarsinogeenisia ominaisuuksia. Tutkimuksessa olemme osoittaneet, että marjakasvien lajikkeiden välillä on huomattavia eroja fenolisten terveyskomponenttien pitoisuuksissa. Ulkomaisissa mustaherukkalajikkeissa (mm. Triton ja Ben Tron) oli selvästi korkeammat flavonolipitoisuudet kuin laajalti viljellyllä Öjebyn lajikkeella. Flavonoleista vadelmassa oli eniten kversetiiniä, jota selvästi oli runsaammin vanhassa Balder lajikkeessa, ja vähiten laajalti viljellyssä Ottavassa. Mansikkalajikkeista eniten oli flavonoleja Honeoye -lajikkeessa, joka on harmaahometta hyvin kestävä lajike, ja vähiten Senga sengana lajikkeessa, joka on harmaahomeelle erittäin altis lajike. Projektissa olemme keränneet lajikenäytteitä sekä luomuna että tavanomaisesti viljellyiltä mansikkatiloilta, ja tutkineet marjojen terveyskomponenttipitoisuuksia. Systemaattisia eroja ei ole löydetty terveyskomponenttien pitoisuuksissa eri tuotantomuotojen välillä, vaan lajike ja tuotantoalue näyttää enemmän vaikuttavan biokemiallisin laatuominaisuuksiin kuin tuotantotapa. Lajikkeiden välillä havaitut suuret erot fenolisissa terveyskomponenttien pitoisuuksissa antaa mahdollisuuden valita tuotantoon erikoislajikkeita, jotka soveltuvat hyvin funktionaalisten elintarvikkeiden raakaaineiksi.
\end{abstract}

\section{Johdanto}

Erilaisten terveysvaikutteisten elintarvikkeiden kulutuksen arvioidaan lisääntyvän voimakkaasti seuraavan kymmenen vuoden aikana. Tällä kehityksellä tulee olemaan myös merkittävä vaikutus alkutuotantoon. Tästä on jo viitteitä nähtävissä, sillä mm. mustaherukan tuotantoalat ovat kasvussa Euroopassa, mikä on paljolti ollut seurausta mustaherukasta tehtyjen jatkojalosteiden kysynnän kasvusta. Mustaherukan tunnetut terveyttä edistävät ominaisuudet tuovat jo koko tuotantoketjuun merkittävän lisäarvon.

Marjojen terveyttävä edistäviä ominaisuuksia on tutkittu runsaasti viime vuosina. Perinteisesti tiedetään, että marjat ovat hyviä $C$-vitamiinin lähteitä, ja että ne sisältävät monipuolisesti kivennäisaineita ja ovat vähäkalorisia. Näiden lisäksi marjoissa on runsaasti erilaisia fytokemikaaleja, terveyttävä edistäviä yhdisteitä, joilla on antioksidanttivaikutuksia (Vinston ym. 2001). Monet tutkimukset osoittavat, että runsas marjojen ja vihannesten syönti, joissa on monipuolisesti fytokemikaaleja ehkäisee sydän ja verisuonitauteja ja eräitä syöpiä (Dillard ja German 2000). Flavonoidit ovat fenolisia terveyskomponentteja, joita on kasveissa yli 4000 erilaista yhdistettä. Viljellyistä marjoistamme mustaherukassa on hyvin runsaasti flavonoideja, erityisesti antosyaaneja, katekiineja, kversetiinia, kemferolia ja myrisetiiniä (Mikkonen ym. 2001a). Sen sijaan mansikassa ja vadelmassa on pääosin vain kversetiiniä ja kemferolia, mutta niissä on hyvin runsaasti fenolihappoja. Ellagihappo muodostaa yli $80 \%$ vadelman ja yli $50 \%$ mansikan flavonolien ja fenolihappojen kokonaispitoisuudesta (Häkkinen ym. 1999). Kversetiinin terveysvaikutuksia on eniten tutkittu fenoliyhdisteistä, ja sen on todettu mm. ehkäisevän syövän syntyyn liittyvien DNA-vaurioiden muodostumista ja LDL- partikkelien hapettumista, joka johtaa ateroskleroosin syntyyn. Ellagihapolla tiedetään olevan antimutageenisia ja antikarsinogeenisia vaikutuksia (Maas ym. 1991). Marjojen lisäksi, mustaherukan (ja tyrnin) siemenöljyt sisältävät terveydelle hyödyllisiä rasvahappoja, joita 
hyödynnetään jo ravintovalmisteissa ja kosmetiikkateollisuudessa. Myös marjakasvien lehdissä on runsaasti fenolisia yhdisteitä, joilla tiedetään olevan mm. mikrobeja ehkäiseviä ominaisuuksia, mutta toistaiseksi lehtien fenolisia yhdisteitä ei juurikaan teollisesti hyödynnetä.

Tutkimustietoa on kertynyt jo melko paljon siitä, miten marjojen fenoliset terveyskomponentit muuttuvat varastoinnin ja erilaisten jalostusprosessien aikana, mutta toistaiseksi tiedetään hyvin vähän, miten eri viljelytoimenpiteet vaikuttavat fenolisiin terveyskomponentteihin. Lajikkeiden välillä on suuria eroja eri terveyskomponenttien pitoisuuksissa, ja eri puolilla maailmaa on myös ryhdytty jalostamaan "flavonoidirikkaita" marjakasvilajikkeita. Lannoituksen ja erilaisten kasvustokäsittelyjen vaikutuksia terveyskomponentteihin ei tunneta juuri ollenkaan. Tässä kirjoituksessa esitellään MTT:n ja Kuopion yliopiston yhteistutkimuksia, joissa on analysoitu marjakasvilajikkeiden fenolisia terveyskomponentteja mansikoista, vadelmista ja mustaherukoista, joita on kerätty sekä tavanomaisesti että luomuna viljellyiltä tiloilta.

\section{Tulokset}

Olemme eri puolilta Suomea keränneet marjakasvien lajikkeita mustaherukasta, mansikasta ja vadelmasta, ja tutkineet niiden fenolisten terveyskomponenttien, erityisesti flavonolien pitoisuuksia. Näytteiksi on valittu kypsyydeltään tasalaatuiset marjat, jotka on välittömästi jäädytetty hiilippojäillä, ja kuljetettu Kuopion yliopistoon analysoitavaksi HPLC:1lä (Mikkonen ym. 2001a). Mustaherukkanäytteitä on kerätty Kuopiosta (Esa Vainikaisen tila, MarjaVasu OY) ja Mikkelistä (MTT, Karila). Kuvasta 1 nähdään, että mustaherukassa esiintyy hyvin runsaana myrisetiiniä ja kversetiiniä, mutta vähiten kemferolia. Lajikkeiden väliset erot ovat hyvin suuria, myrisetiiniä on runsaasti erityisesti Triton ja Ben Tron lajikkeilla, mutta selvästi vähemmän Mortti, Ola, Hangaste ja Öjebyn lajikkeilla. Olennaisia eroja ei löydetty fenolisten terveyskomponenttien pitoisuuksissa luomu -ja tavanomaisesti viljellyistä mustaherukoista. Mustaherukan fenoliyhdisteiden runsaus selittänee keskeisesti mustaherukan voimakkaan antioksidanttivaikutuksen ja antaa tukevan pohjan mustaherukkaan perustuville terveysvaikutteisten tuotteiden kehittämiselle.

Vadelmalajikkeita olemme keränneet erityisesti Kiteeltä (Kiteen vadelma KY) ja Kuopion yliopiston puutarhan koekentältä. Flavonoleista vadelmassa on eniten kversetiiniä, jota olemme tutkineet sen tunnetun terveysvaikutuksen vuoksi. Kuvasta 2 näemme, että vadelmalajikkeiden kversetiinipitoisuudessa on huomattavia eroja; yleisesti viljellyssä Ottavassa on selvästi vähemmän kversetiiniä kuin vanhassa Balderissa. Myös Preussenissa ja Maurin makeassa on enemmän kversetiiniä kuin Ottavassa. Verrattuna mustaherukkaan, kversetiinipitoisuudet ovat vadelmassa hyvin pienet. Sekä vadelman että mustaherukan tulokset osoittavat, että fenolisten terveyskomponenttien pitoisuuksissa lajikkeiden väliset erot ovat hyvin suuret, ja funktionaalisten raaka-aineiden materiaaliksi voidaan valita korkeapitoisia lajikkeita. Lajikkeiden välinen suuri pitoisuuksien vaihtelu antaa myös hyvän pohjan määrätietoiselle jalostustyölle.

Mansikkalajikkeita olemme keränneet eri puolilta Suomea sekä tavanomaisesti että luomuna viljellyiltä tiloilta. Mansikasta olemme tutkineet ellagihapon, kversetiinin ja kemferolin pitoisuuksia (Mikkonen ym. 2001b). Suurimmat fenoliyhdisteiden pitoisuudet olemme löytäneet Honeoye lajikkeesta, ja matalimpia edustaa Senga sengana lajike. Näistä edellinen on harmaahometta parhaiten kestävä, ja jälkimmäinen taudille kaikkein altteimpia. Fenoliset terveyskomponentit ovat kasvin sekundaariaineenvaihdunnan tuotteita, jotka ovat kehittyneet kasveihin miljoonien vuosien kuluessa kasvin puolustautuessa tauteja ja hyönteisiä sekä muita stressejä vastaan. On biologisesti vain sattumaa, että nämä samat kasvin suoja-aineet on myöhemmin havaittu myös hyväksi ihmisen terveydelle. Luomutuotannon kannalta voidaan ajatella, että olisi eduksi, jos kasvin suoja-aineiden pitoisuudet olisi korkeita, koska tällöin luontainen taudinkestävyys pitäisi paremmin taudit kurissa. Olemme keränneet näytteitä samoista lajikkeista sekä luomuna että tavanomaisesti viljellyiltä tiloilta, ja tutkineet, eroavatko lajikkeet fenolisten terveyskomponenttien pitoisuuksien suhteen. Esimerkkejä tuloksista esittävät kuvat $3 \mathrm{a}$, b, joista nähdään, että systemaattista eroa kummankaan hyväksi ei ole, vaan eri paikoissa ja eri lajikkeilla pitoisuudet vaihtelevat tuotantotavasta riippumatta. Esimerkiksi kversetiiniä on eniten Jonsok- lajikkeessa Karjalohjan luomutilalla, mutta kemferolia on eniten tavanomaisesti viljellyllä Juhmon marjatilalla; toisella lajikkeella (Dania, 3 a) pitoisuudet ovat samaa tasoa luomuna ja tavanomaisesti viljelynä. Kallion ym. (2000) tutkimuksissa ei havaittu myöskään merkittäviä eroja tavanomaisesti ja luomuna viljeltyjen mansikkalajikkeiden sokeri - ja happopitoisuuksissa. Näyttää ilmeiseltä, että lajike ja tuotantoalue on biokemiallisiin laatuominaisuuksiin enemmän vaikuttava tekijä kuin tuotantotapa. Toistaiseksi tutkimuksia on voitu 
tehdä vain muutamien tilojen vertailuina, ja olisi tärkeätä laajentaa biokemiallisia laatututkimuksia useiden luomutilojen ja tavanomaisesti viljeltyjen marjatilojen vertailuun.

\section{Yhteenveto}

Marjakasvit sisältävät C-vitamiinin ja kivennäisaineiden lisäksi monia ihmisen terveyteen edullisesti vaikuttavia fenolisia fytokemikaaleja. Runsaimmin fenolisia yhdisteitä on mustaherukassa, lähes yhtä paljon kuin luonnon marjoisssa. Mustaherukassa on monipuolisesti erilaisia flavonoideja, mutta mansikka ja vadelma sisältävät hyvin paljon fenolihappoihin kuuluvaa ellagihappoa, jolla tiedetään olevan antimutageenisia -ja antikarsinogeenisia vaikutuksia. Lajikkeiden välillä on huomattavia eroja fenolisten terveyskomponenttien pitoisuuksissa. Erityistarkoituksiin, $\mathrm{mm}$. funktionaalisten elintarvikkeiden raaka-aineiksi voidaan valita korkeapitoisia lajikkeita. Systemaattisia eroja ei ole löydetty marjalajikkeiden terveyskomponenttien pitoisuuksissa eri tuotantomuotojen välillä (luomu versus tavanomainen). Lajikkeella ja tuotantopaikalla näyttää olevan suurempi merkitys kuin tuotantotavalla terveyskomponenttien pitoisuuksiin.

\section{Kirjallisuus}

Dillard, C. \& J. German 2000. Phytochemicals: Nutraceuticals and human health. J. Sci Food Agric. 80: 17441756

Häkkinen, S., Heinonen, M., Kärenlampi, S., Mykkänen, H., Ruuskanen, J. \& Törrönen, R. 1999. Screening of selected flavonoids and phenolic acids in 19 berries. Food Res Int. 32: 345-353

Maas, J. \& Galletta, G.J. 1991. Ellagic acid, an anticarsinogen in fruits, especially in strawberries: A review: Hort Sci 26: 10-14

Mikkonen, T., Määttä, K., Hukkanen, A., Kokko, H., Törrönen, R., Kärenlampi, S.\& Karjalainen, R. 2001. Flavonol content varies among black currant cultivars. J. Agric.Food Chem. 49: 3274-3277

Mikkonen, T., Hukkanen, A., Määttä, K., Kokko, H., Törrönen, R., Kärenlampi, S. \& Karjalainen, R. 2001. Flavonoid content in strawberry cultivars. Acta Hortic. (in press)

Vinston, J., Su, X., Zubik, L. \& Bose, P. 2001. Phenol antioxidant quantity and quality in foods: Fruits. J. Agric.Food Chem. 49: 5315-5321

\section{Kuvatekstit:}

Kuva1. Mustaherukkalajikkeiden fenolisten terveyskomponenttien pitoisuudet (flavonolipitoisuudet, myrisetiini, kversetiini ja kemferoli) eri lajikkeilla (viljelypaikka, Mikkeli, MTT, Karila)

Kuva 2. Vadelmalajikkeiden kversetiinipitoisuuden vaihtelu (viljelypaikka, Kuopio, yliopiston puutarha)

Kuva 3. Mansikkalajikkeiden fenolisten terveyskomponenttien (flavonolit; kversetiini jakemferoli) pitoisuudet eri tiloilla (luomu versus tavanomianen). Vasen kuva 3a, Dania- lajike; oikea kuva 3 b, Jonsok -lajike 


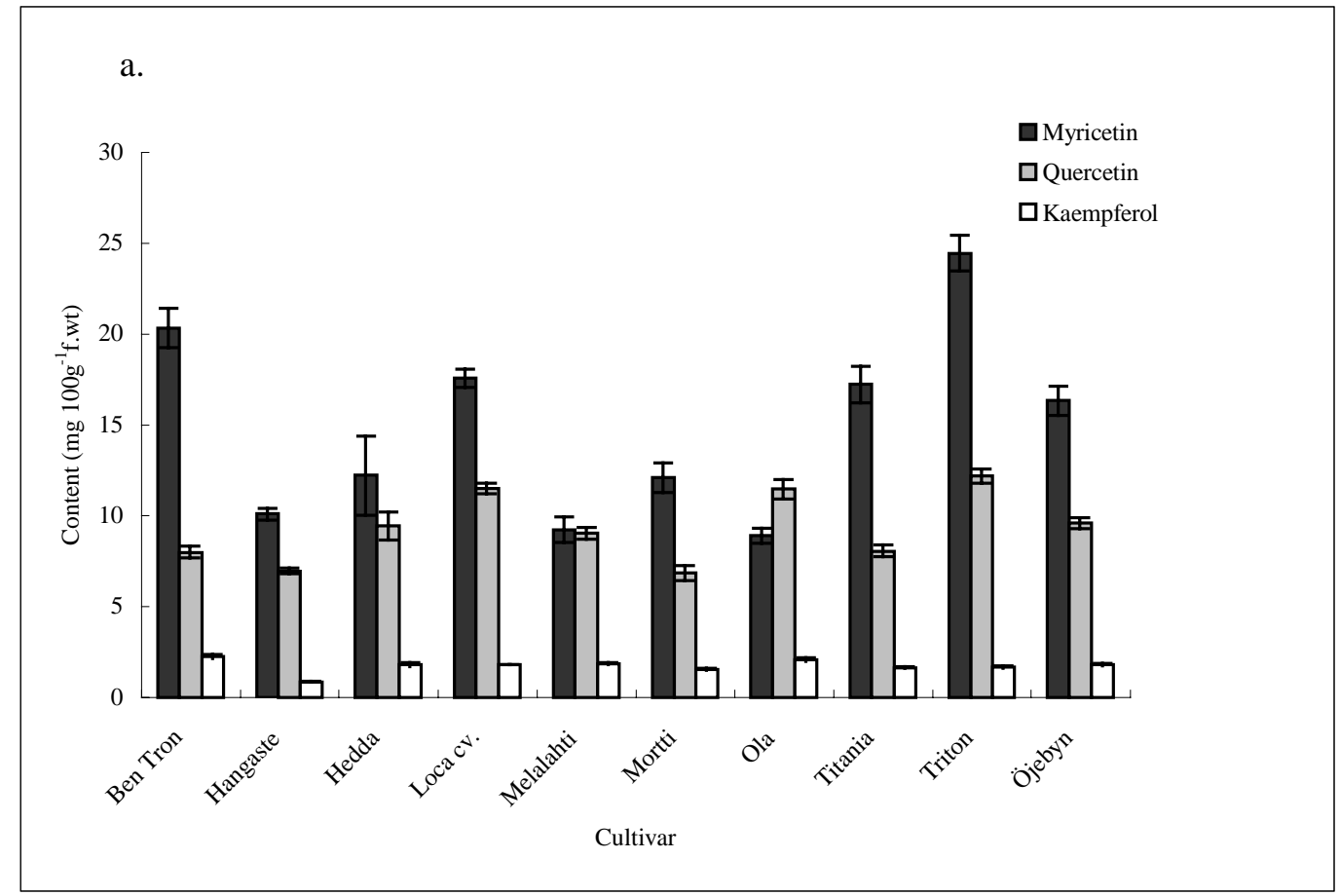

Kuva 1

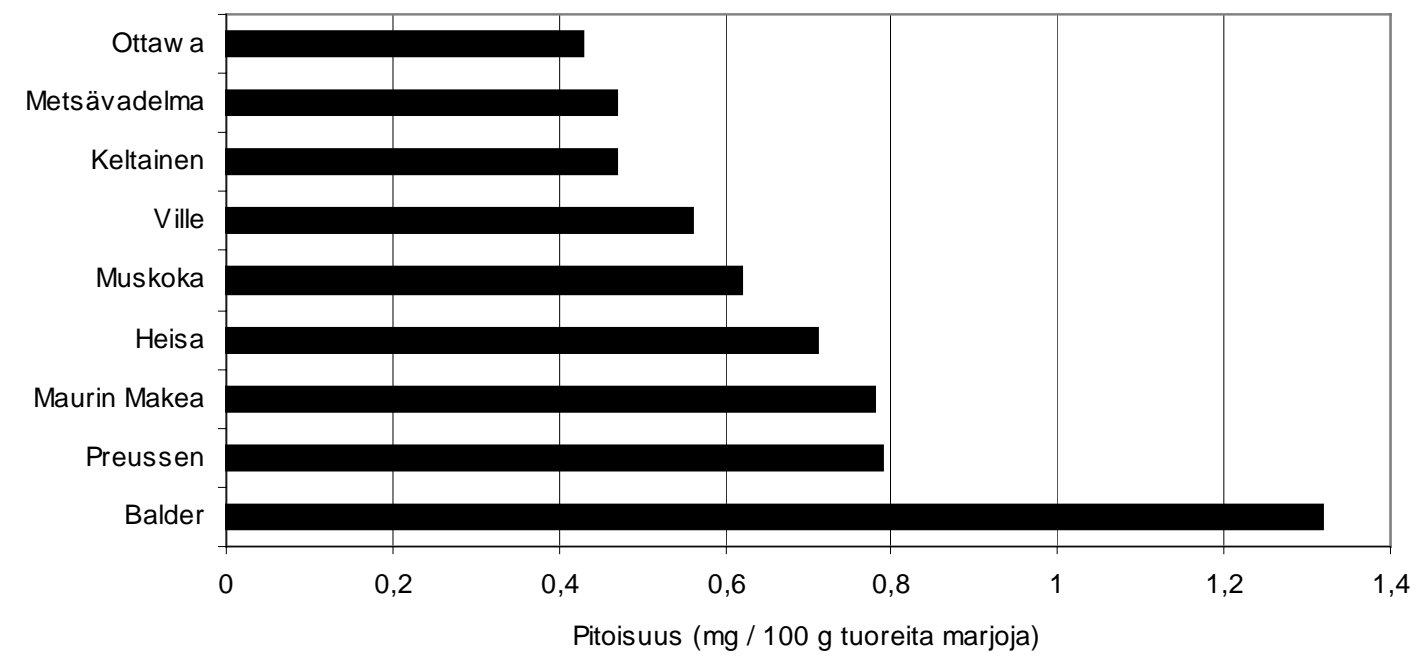

Kuva 2
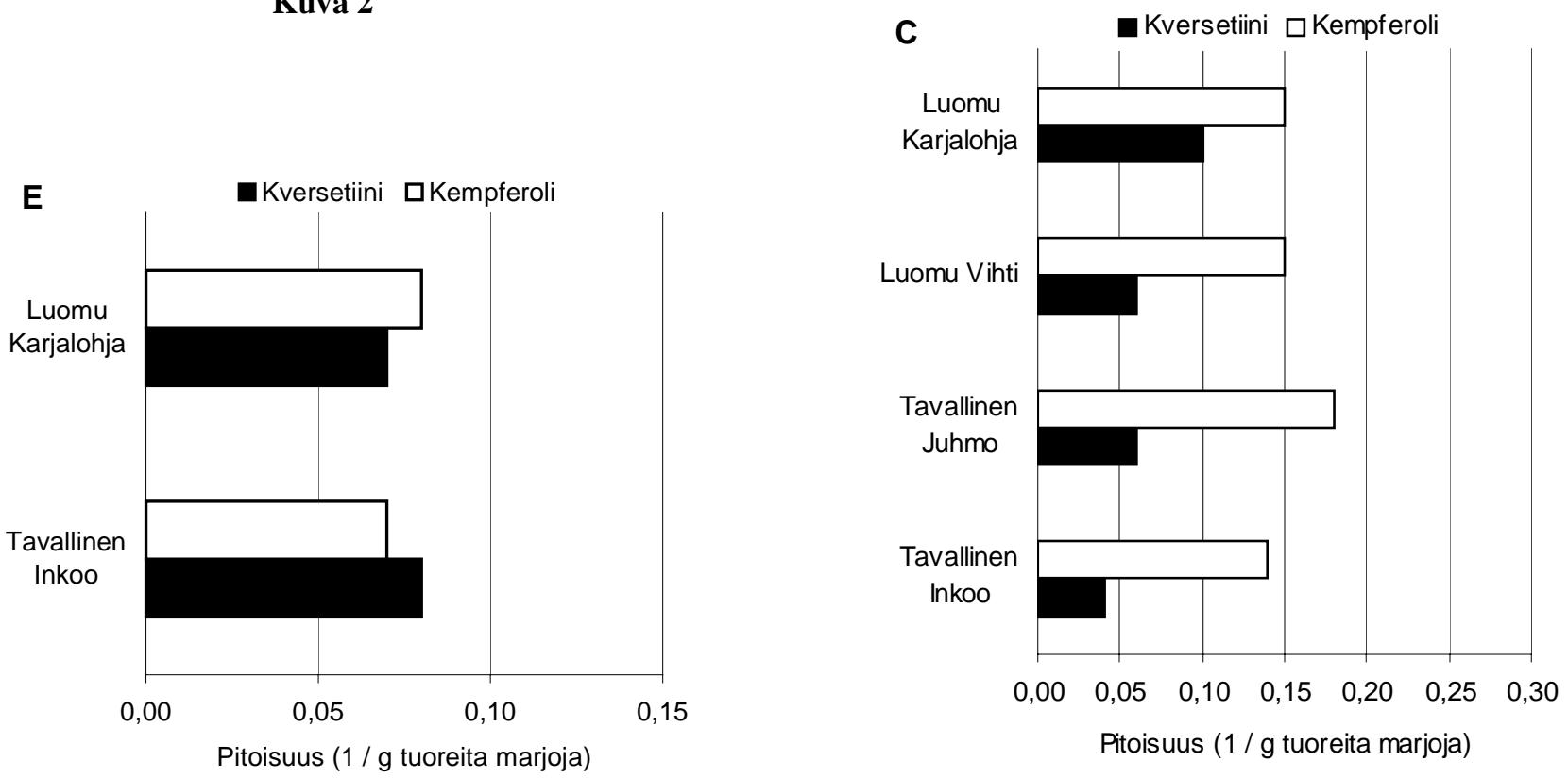